monuments. Then again, Northern Ireland has yielded important Mesolithic industries, the study of which is still incomplete. Nor must relics of later periods be forgotten, and crannogs, earth-forts, etc., have received attention. Further, it has been realized that excavation without subsequent publication is of little worth.

Naturally, much of the new information has found its way into the older well-known archæological journals and proceedings, but special reference must be made to the Ulster Journal of Archoeology, which has just publiched its sixth volume, containing an account by the editor of the archæological achievement of the last ten years. The reader will certainly find this publication eclectic in its interests, and much curious and interesting information on subjects ranging from prehistoric to modern can be culled from its pages. It is to be regretted that England, during the periods of acute unemployment, did not follow the lead given by Ireland. Of course, here, as indeed in Ireland too, museums and local archæological societies make grants for the purposes of excavation. But direct Government aid of the kind mentioned above gives an immense fillip to such work, and there is a direct return to the body politic, which is scarcely the case when the money is merely spent in 'doles'. The Irish method at least means that more becomes known of the country's past.

\section{Labour in the Building Industry}

A RECENT broadsheet (No. 212) issued by Political and Economic Planning contains a close analysis of the organization of the labour force in the building industry in Great Britain, nationally, on the site and in the trade unions, which represents part of a wider study of industrial relations which was undertaken before, but was interrupted by, the War. The analysis covers all sizes and types of unit, from the very large firms down to the small firms and their groups. It gives a clear picture of the organization of labour on the site including the organizing personnel, the recruitment of foremen and the part played by the trade unions, as well as of the organization of labour in the unions, including the federation branch, the executive committee, the National Joint Council, the rates of wages and payment by results. In the postwar period the latter question will be linked with the questions of prefabrication and of new and more flexible types of training, and the essential changes of practice are unlikely to be secured without a sense of urgency and without Government intervention which can be visualized only as part of a great plan of guaranteed employment for the building industry. With guaranteed employment all sorts of technically desirable changes may well become more acceptable, but the goodwill of the trade unions is indispensable, and this can only be obtained by full and frank consultation, and by democratic discussion both at the national level, in the localities and on the site.

\section{Scientific Societies of North America}

The U.S. National Research Council has produced a fourth edition of its "Handbook of Scientific and Technical Societies and Institutions of the United States and Canada" (Bull. 106, Jan. 1942. Washington, D.C. : National Academy of Sciences). This well-bound volume of 389 large pages contains information relating to 1,269 bodies in the United States and its dependencies, and 143 in Canada, which "contribute to the advancement of knowledge through their meetings, publications or other resources", and are included in the wide fields of natural sciences, technology and more general organ. izations supporting scientific research. Agencies of the Federal Government, organizations directly controlled by universities, bodies which act through grants rather than direct by conducting research, and industrial research laboratories are excluded. In each case there are given the name and address of the organization, the chief officers, a brief history, its objects, particulars of membership, meetings, research funds and medals, and serial publications. The data have been compiled from information received from the bodies concerned. The entries are arranged alpha. betically in two sections, one for the United States and one for Canada. There are subject and personnel indexes for each section. The only comparable publication in Great Britain is the "Official Year-Book of the Scientific Societies of Great Britain and Ireland", published by Messrs. Charles Griffin and Co., Ltd., for many years, but discontinued since the beginning of the War. Such reference books are of much value in the library and elsewhere.

\section{Rare Scientific Books}

CATalogue 8 (Spring 1943) issued by Schuman's, 20 East 70th Street, New York, contains 485 items, the great majority of which are of medical interest, but including a number of non-medical scientific works as well. Special mention may be made of the following : several works by Vesalius including the third edition of the "Fabrica", the first edition of Casserio's "Tabulæ Anatomicæ" (1627), Fallopio's "Institutiones Anatomicæ" (1585), the first edition of Acosta's "Herbal" (1578), Cesalpino's "De Plantis" (1583) ; Fracastor's "Opera Omnia" (1555), the first edition of Conrad Gesner's "Surgical Tracts" (1516-65), Hans Sachs' folk poem (c. 1550), the first edition of Guido Guidi's work on surgery (1544), the first edition of Cockayne's "Leechdoms" (1864-66), the first edition of Morgagni's "De Sedibus et Causis Morborum" (1761). The non-medical works include the first edition of Goethe's "Metamorphose der Pflanzen" (1790), the first edition of Lyell's "Geological Evidence of the Antiquity of Men" (1863), the first edition of Newton's "Optics" (1704) and the first edition of the "Origin of Species" (1859), and Francis Hauksbee's "Physico-Mechanical Experiments on various Substances" (1709).

\section{Announcements}

A sPECIAC meeting to commemorate the life and work of Nikola Tesla will be held at the Institution of Electrical Engineers on November 25, at 3 p.m. At the meeting a lecture, with examples of Tesla's experimental work, will be delivered by Dr. A. P. M. Fleming, director and manager, Research and Education Departments of Messrs. MetropolitanVickers Electrical Co., Ltd.

Is reviewing Prof. J. C. Slater's 'Introduction to Chemical Physics" in Nature of October 30 , p. 488 , the price of the book quoted was that of the time of issue, namely, 33s. ; we are informed by the MeGrawHill Book Co., Inc., that the current price is $35 s$.

Erratum. In Nature of November 6, p. 535, col. 2, line 1, for "flies is not due to mechanical inability to reach the goal", read "flies is due to mechanical inability to reach the goal". 